
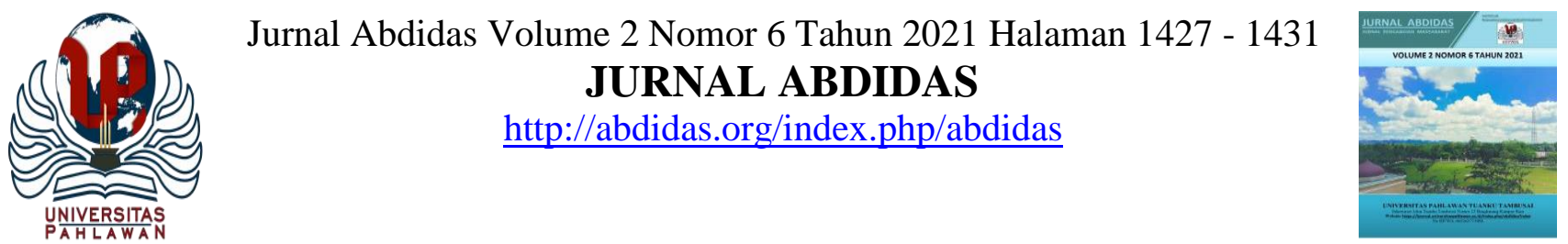

\title{
Aksi Vaksinasi Peduli Covid- 19 dan Gerakan Kembali ke Kampus di STIE Bina Karya Tebing Tinggi
}

\author{
Sri Hardiyanti Damanik ${ }^{1}$, Rakhmawati Purba ${ }^{2}$, Suci Etri Jayanti S. ${ }^{3}$ \\ Sekolah Tinggi Ilmu Ekonomi Bina Karya Tebing Tinggi, Indonesia ${ }^{1,2,3}$ \\ E-mail: sriwindahardiyantid@gmail.com ${ }^{1}$ rakhma.purba@gmail.com ${ }^{2}$ sucietrijayanti@gmail.com ${ }^{3}$
}

\begin{abstract}
Abstrak
Pelaksanaan pembelajaran tatap muka terbatas dimasa pandemi Covid-19 mewajibkan seluruh akademisi pendidikan diwajibkan untuk mendapatkan vaksinasi, termasuk di STIE Bina Karya Tebing Tinggi. Hal ini sesuai dengan surat keputusan bersama 4 (empat) menteri No. 23425/A5/ HK.01.04/2021 tanggal 8 Agustus 2021 perihal panduan penyelengaraan pembelajaran di masa pandemi Covid-19 dan instruksi Gubernur Sumatera Utara No. 188.54/39/INST/2021 tanggal 30 Agustus 2021. Uraian permasalahan inti dari kegiatan pengabdian masyarakat ini adalah membantu program pemerintah dalam percepatan tingkat pencapaian vaksinasi di lingkungan pendidikan dan memenuhi kewajiban dalam melakukan kegiatan pembelajaran tatap muka di lingkungan akademik. Metode yang dilakukan dalam pengabdian ini adalah melalui perencanaan, pelaksanaan dan evaluasi. Metode evaluasi yang digunakan dalam kegiatan ini adalah reduksi data. Hasil dalam pengabdian ini adalah kegiatan berjalan maksimal dalam rangka memutus mata rantai penyebaran Covid-19 di kota Tebing Tinggi. Pencapaian target dalam kegiatan ini sudah mencapai 100 persen. Implementasi dari kegiatan pengabdian ini masih terjadi adanya kekurangan dalam pelaksanaan aksi vaksinasi peduli covid-19 dan gerakan kembali ke kampus terletak pada kuota vaksin yang terbatas untuk masyarakat dan terpenuhi untu sivitas akademik STIE Bina Karya Tebing Tinggi.
\end{abstract}

Kata kunci: vaksin, peduli, gerakan kampus

\begin{abstract}
The implementation of limited face-to-face learning during the Covid-19 pandemic requires all Education Academics to be vaccinated, including at STIE Bina Karya Tebing Tinggi. This is in accordance with the joint decree of 4 (four) ministers No. 23425/A5/HK.01.04/2021 dated August 8, 2021 regarding guidelines for organizing learning during the Covid-19 pandemic and instructions from the Governor of North Sumatra No. 188.54/39/INST/2021 dated August 30, 2021. The description of the core problem of this community service activity is to assist government programs in accelerating the level of attainment of vaccinations in the educational environment and fulfilling obligations in conducting face-to-face learning activities in the academic environment. The method used in this service is through planning, implementation and evaluation. The evaluation method used in this activity is data reduction. The result of this service is that activities run optimally in order to break the chain of the spread of Covid in the city of Tebing Tinggi. The achievement of the target in this activity has reached 100 percent. The implementation of this service activity is still lacking in the implementation of the Covid-19 vaccination action and the movement back to campus lies in the limited vaccine quota for the community and is fulfilled for the academic community of STIE Bina Karya Tebing Tinggi.
\end{abstract}

Keywords: vaccine, care, campus activity

Copyright (c) 2021 Sri Hardiyanti Damanik, Rakhmawati Purba, Suci Etri Jayanti S

$\triangle$ Corresponding author

Address : STIE Bina Karya Tebing Tinggi

Email : rakhma.purba@gmail.com

DOI $:$ https://doi.org/10.31004/abdidas.v2i6.487

ISSN 2721-9224 (Media Cetak)

ISSN 2721- 9216 (Media Online)

Jurnal Abdidas Vol 2 No 6 Tahun 2021 p-ISSN 2721-9224 e-ISSN 2721-9216 
1428 Aksi Vaksinasi Peduli Covid- 19 dan Gerakan Kembali ke Kampus di STIE Bina Karya Tebing Tinggi Sri Hardiyanti Damanik, Rakhmawati Purba, Suci Etri Jayanti S

DOI: https://doi.org/10.31004/abdidas.v2i6.487

\section{PENDAHULUAN}

Badan kesehatan dunia (WHO) telah menetapkan wabah yang dihadapi yaitu Covid-19 sebagai pandemik secara mendunia (Sari Hartini dkk, 2020). Sejak bulan Maret 2020, di Indonesia pandemik Covid telah menyebar dan menimbulkan dampak yang sangat signifikan di berbagai aspek aktivitas manusia, yaitu ekonomi, kesehatan, dan budaya termasuk bidang pendidikan (Triyo Rachmadi dkk, 2021).

Kampus merupakan lembaga pendidikan yang menjadi solusi untuk memupuk karakter dan jati diri bangsa. Sistem tersebut juga tidak luput dari peran Dosen yang menjadi meditor dalam pelaksanaan kurikulum (Damanik \& Purba, 2021) Mengingat Covid tidak hanya berkeliaran di daerah perkotaan, namun di pedesaan juga, Karena virus ini adalah virus bawaan dari orang yang berada di daerah terkena virus. Dan virus ini tidak bisa dijangkau oleh mata, namun terasa dalam diri manusia dengan salah satu cirinya adalah batuk yang keras (Hasriani \& Sukarta, 2021).

Berbagai upaya dan strategi yang dilakukan tidak serta merta menghentikan penyebaran Covid19 hingga kini. Oleh karena itu pemerintah mewajibkan seluruh warga Indonesia melakukan vaksinasi Covid-19, dengan tujuan menciptakan kekebalan tubuh agar masyarakat menjadi lebih kuat imunitas dalam melawan virus corona tersebut. Vaksin adalah bahan antigenik yang digunakan untuk menghasilkan kekebalan tubuh terhadap suatu penyakit (Ayunda et al., 2020). Hal ini berdampak positif pada kegiatan masyarakat dalam menjalankan aktivitas kesehariannya (Dewi \& Bustan, 2021).
Salah satu tujuan dilaksanakannya gerakan vaksinasi kampus menjadi salah satu kewajiban yang diarahkan pemerintah dalam melakukan pembelajaran tatap muka. Baik tenaga pendidik dan sivitas akademik beserta mahasiswa wajib mendapatkan vaksinasi sebelum kegiatan pembelajaran tatap muka dilakukan.

Tujuan kegiatan pengabdian kepada masyarakat dengan Judul "Strategi Vaksinasi Peduli Covid-19 dalam Mendukung Gerakan Pemerintah di STIE Bina Karya Tebing Tinggi” bertujuan untuk Mengimplementasikan Tridharma Perguruan Tinggi, Khususnya Pengabdian Kepada Masyarakat dan mendukung upaya pemerintah untuk menanggulangi penurunan tingkat penularan Covid-19 secara Nasional.

\section{METODE}

Metode pelaksanaan yang dilakukan pada pengabdian ini adalah menggunakan strategi penyuluhan dalam memberikan sosialisasi dan informasi tentang pemberian vaksinasi Covid-19 kepada masyarakat terutama kepad tenaga pendidik, sivitas akademik dan mahasiswa. Dari hasil pemberian penyuluhan dan informasi tersebut terdata peserta yang menjadi sasaran vaksinasi.

Tahap metode pelaksanaan yang dilakukan, yaitu : perencanaan, pelaksanaan dan evaluasi. Dalam tahap perencanaan dilakukan pertemuan kordinasi dengan pihak Polres Tebing Tinggi, RS Bhayangkara Tebing Tinggi dan STIE Tebing Tinggi untuk menetapkan pembagian tugas tim, menentukan lokasi, waktu pemberian vaksinasi dan sasaran vaksinasi. 
1429 Aksi Vaksinasi Peduli Covid- 19 dan Gerakan Kembali ke Kampus di STIE Bina Karya Tebing Tinggi Sri Hardiyanti Damanik, Rakhmawati Purba, Suci Etri Jayanti S

DOI: https://doi.org/10.31004/abdidas.v2i6.487

Pada tahap pelaksanaan, kegiatan yang dilakukan adalah menghimbau dan mengajak seluruh tenaga pendidik, sivitas akademik dan mahasiswa ke lokasi vaksinasi (kampus STIE Bina Karya Tebing Tinggi). Selanjutnya tim vaksinasi memberikan pelayanan kepada peserta vaksinasi dengan alur sebagai berikut :

1. Peserta yang hadir diwajibkan mematuhi protokol kesehatan secara umum.

2. Mengisi daftar hadir beserta kelengkapan data diri.

3. Melakukan screening riwayat kesehatan.

4. Memberikan suntik vaksin covid-19.

5. Mengentry data dan mencetak sertifikat.

6. Memantau kondisi kesehatan pasca penyuntikan vaksinasi kurang lebih 30 menit.

Tahap terakhir yang dilakukan adalah tahap evaluasi, yang meliputi kegiatan:

1. Analisis jumlah peserta yang divaksinasi.

2. Menganalisis sisa stock vaksin yang masih tersedia.

3. Merencanakan tindak lanjut untuk pemberian vaksinasi dosis 2 .

Metode evaluasi yang digunakan dalam kegiatan ini adalah reduksi data. Menurut (Sugiyono, 2018) reduksi data adalah merangkum, memilih hal-hal pokok, memfokuskan pada hal-hal yang penting sesuai dengan topik penelitian, mencari tema dan polanya, pada akhirnya memberikan gambaran yang lebih jelas dan mempermudah untuk melakukan pengumpulan data selanjutnya.

Pencapaian target dalam kegiatan ini diharapkan mencapai 100 persen di kalangan Sivitas Akademika STIE Bina Karya Tebing
Tinggi dengan harapan mendukung kegiatan kembali ke kampus yang dicanangkan pemerintah.

\section{HASIL DAN PEMBAHASAN}

Kegiatan vaksinasi yang telah dilakukan oleh STIE Bina Karya Tebing Tinggi yang bekerjasama dengan Polres dan Rumah Sakit Bhayangkara Kota Tebing Tinggi, dilakukan 2 (dua) kali suntukan vaksin. Suntikan pertama dengan dosis $0,5 \mathrm{ml}$ jenis vaksin Sinovac, dilakukan pada tanggal 23 September 2021 sebanyak 250 peserta, dan tanggal 25 September 2021 sebanyak 150 peserta. Pelaksanaan dimulai dari jam 08.00 wib sampai dengan 13.00 wib.

Kegiatan vaksinasi dosis ke 2 (dua) dilakukan pada tanggal 20 Oktober 2021 sebanyak 250 peserta dan tanggal 23 Oktober 2021 sebanyak 150 peserta dengan jenis vaksin yang sama yaitu Sinovac, dosis $0,5 \mathrm{ml}$ dan waktu pelaksanaan vaksinasi jam 09.00 wib sampai 13.30 wib.

Dampak kegiatan pengabdian masyarakat ini melalui kegiatan pemberian vaksinasi Covid-19 kepada seluruh keluarga besar STIE Bina Karya dan masyarakat umum menghasilkan suatu pemahaman dan perubahan pola pikir tentang pencegahan penularan virus Covid-19.

Antusias seluruh peserta vaksinasi dalam kegiatan pengabdian masyarakat dengan judul Strategi Vaksinasi Peduli Covid-19 dalam Mendukung Gerakan Pemerintah di STIE Bina Karya Tebing Tinggi berjalan dengan baik sesuai dengan target yang telah direncanakan.

Metode evaluasi yang digunakan dalam kegiatan ini adalah reduksi data. Menurut Sugiono (2018) reduksi data adalah merangkum, memilih 
1430 Aksi Vaksinasi Peduli Covid- 19 dan Gerakan Kembali ke Kampus di STIE Bina Karya Tebing Tinggi Sri Hardiyanti Damanik, Rakhmawati Purba, Suci Etri Jayanti S

DOI: https://doi.org/10.31004/abdidas.v2i6.487

hal-hal pokok, memfokuskan pada hal-hal yang penting sesuai dengan topik penelitian, mencari tema dan polanya, pada akhirnya memberikan gambaran yang lebih jelas dan mempermudah untuk melakukan pengumpulan data selanjutnya.

Dalam pelaksanaan kegiatan ini, panitia mengklasifikasikan data peserta yang telah mendapatkan vaksin dosis 1 dan yang belum mendapatkan vaksinasi. Bagi Sivitas yang belum mendapatkan vaksinasi diwajibkan menjadi peserta dan didaftarkan untuk menerima suntikan vaksin dosis 1 .

Pencapaian target dalam kegiatan ini sudah mencapai 100 persen. Hal ini dibuktikan dengan keluarnya sertifikat vaksin tahap 1 (satu) dan 2 (dua) dari seluruh Sivita Akademik STIE Bina Karya Tebing Tinggi dan surat izin dari pemerintah setempat (Walikota Tebing Tinggi) untuk memberlakukan pembelajaran secara tatap muka (off line).

Adapun dokumentasi pada kegiatan pengabdian ini terliat pada gambar dibawah ini

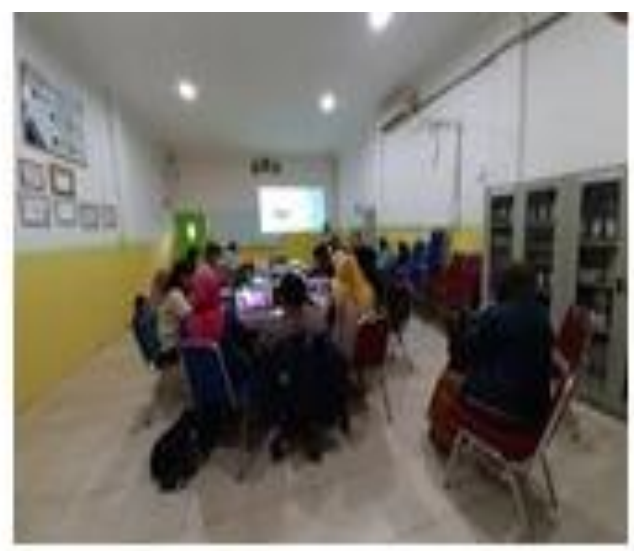

Gambar 1. Rapat Persiapan dan Perencanaan

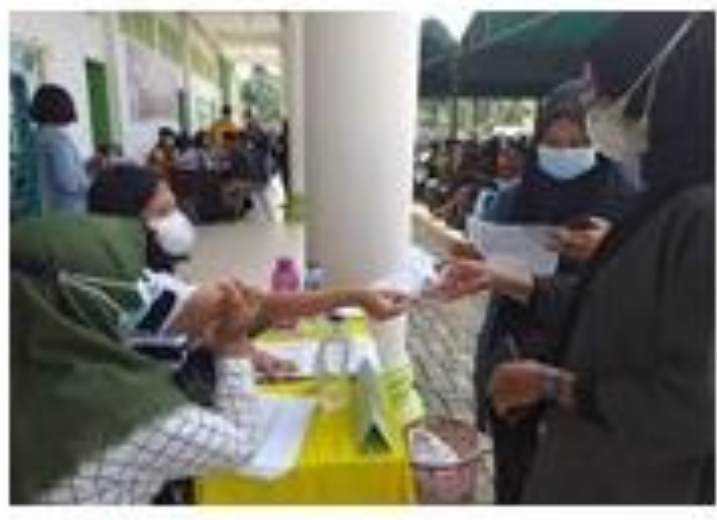

Gambar 2. Kegiatan Vaksinasi

\section{SIMPULAN}

Dengan diadakannya kegiatan pengabdian masyarakat melalui Strategi Vaksinasi Peduli Covid19 dalam Mendukung Gerakan Pemerintah di STIE Bina Karya Tebing Tinggi berjalan maksimal dalam rangka memutus mata rantai penyebaran Covid-19 di kota Tebing Tinggi.

Kegiatan vaksinasi di STIE Bina Karya Tebing Tinggi sesuai dengan surat keputusan bersama 4 (empat) menteri No. 23425/A5/ HK.01.04/2021 tanggal 8 Agustus 2021 perihal panduan penyelengaraan pembelajaran di masa pandemik Covid-19 dan instruksi Gubernur Sumatera Utara No. 188.54/39/INST/2021 tanggal 30 Agustus 2021 tentang pelaksanaan pembelajaran tatap muka terbatas dimasa pandemik Covid-19. Kekurangan dalam pelaksanaan kegiatan ini terletak pada kuota vaksin yang terbatas tetapi antusias masyarakat tinggi.

\section{UCAPAN TERIMA KASIH}

Ucapan terima kasih terutama ditujukan kepada seluruh keluarga besar STIE Bina Karya Tebing Tinggi, Polres dan Rumah Sakit Bayangkara 
1431 Aksi Vaksinasi Peduli Covid- 19 dan Gerakan Kembali ke Kampus di STIE Bina Karya Tebing Tinggi Sri Hardiyanti Damanik, Rakhmawati Purba, Suci Etri Jayanti S

DOI: https://doi.org/10.31004/abdidas.v2i6.487

Kota Tebing Tinggi atas partisipasi dalam kegiatan

Strategi Vaksinasi Peduli Covid-19 dalam

mendukung gerakan pemerintah.

\section{DAFTAR PUSTAKA}

Ayunda, R., Kosasih, V., \& Disemadi, H. S. (2020). Perlindungan Hukum Bagi Masyarakat Terhadap Efek Samping Pasca Pelaksanaan Vaksinasi Covid-19 Di Indonesia. Nusantara: Jurnal Ilmu Pengetahuan Sosial, 7(2), 408-420.

Damanik, S. W. H., \& Purba, R. (2021). Strategi pola asuh pendidikan anak usia dini di masa pandemik covid-19 pada PAUD Ar Raudah. BERNAS: Jurnal Pengabdian Kepada Masyarakat, 2(1), 206-210. https://doi.org/10.31949/jb.v2i1.688

Dewi, A., \& Bustan, R. (2021). Sosialisasi Vaksinasi Covid-19 Dan Protokol Kesehatan 7 M Sebagai Upaya Pencegahan Penyebaran Virus Covid-19. SNPPM-3 (Seminar Nasional Penelitian Dan Pengabdian Kepada Masyarakat), 3(2), 58-66.

Hasriani, S., \& Sukarta, A. (2021). Aksi Peduli COVID-19 Berupa Sosialisasi dan Gerakan Vaksinasi sebagai Adaptasi Merdeka Belajar Kampus Merdeka ITKES Muhammadiyah Sidrap Bersama Lawan COVID. 1(2), 345350.

Sari Hartini dkk. (2020). Kepedulian Stmik Nusa Mandiri Bersama Lawan Covid-19. 2(1), 14.

Sugiyono. (2018). Metode Penelitian Kuantitatif. CV. Alfabeta.

Triyo Rachmadi dkk. (2021). Pemberian Vaksinasi COVID-19 Bagi Masyarakat Kelompok Petugas Pelayanan Publik di Kecamatan Buluspesantren. JURPIKAT (Jurnal Pengabdian Kepada Masyarakat), 2(2), 104119. https://doi.org/10.37339/jurpikat.v2i2.643 